\title{
Ecogeographic survey and gap analysis for Medicago L.: recommendations for in situ and ex situ conservation of Lebanese species
}

\author{
Jostelle Al Beyrouthy • Nisrine Karam • Mohammad S. Al-Zein • \\ Mariana Yazbek
}

Received: 22 January 2019/Accepted: 11 March 2019/Published online: 1 April 2019

(C) The Author(s) 2019

\begin{abstract}
Medics (Medicago spp.) are among the most important pasture legumes of temperate regions. Lebanon is considered as a part of the Mediterranean biodiversity hotspot in Medics. Its flora including more than 35 species of medics, most of which, not unlike this country's flora, are threatened. To alleviate these threats, large accessions of Medicago were collected for ex situ conservation; however, some species are underrepresented and sometimes not represented in genebanks, and many species are not protected, particularly because of the lack of in situ conservations strategies. In this study, we produced an updated checklist and distribution maps of Lebanese medics. Later we identified priority species for collection and priority areas for ecogeographic surveys and conservation by using gap analysis. Out of the 37 species reported from Lebanon, six were found to be priority species for collecting. Gap analysis also revealed that priority areas for surveying and
\end{abstract}

J. Al Beyrouthy · M. Yazbek ( $\square)$

Genetic Resources Section, International Center for

Agricultural Research in Dry Areas (ICARDA), Beirut,

Lebanon

e-mail: M.Yazbek@cgiar.org

\section{N. Karam}

Faculty of Agriculture, Lebanese University, Beirut, Lebanon

\section{S. Al-Zein}

Department of Biology, American University of Beirut, Beirut, Lebanon conservation are located mostly in the northern, southern and eastern parts of the country. Out of the currently established natural reserves, the Shouf Cedar Reserve had the highest diversity of Medicago species. Beirut and Tripoli (both major coastal cities) and Zahle (one of the major cities in the Bekaa valley) have excellent to very highly suitable sites with the highest genetic diversity of medics. Therefore, they constitute with areas along the northern border of the country, priority locations for establishing in situ conservation sites (genetic reserves) because the two locations are very rich in priority species. Other priority species are found in the southern part of Lebanon and could be ex situ conserved.

Keywords Medicago $\cdot$ Rangeland plants $\cdot$ Forage species - Lebanon - Gap analysis - Ex situ conservation · In situ conservation · DIVA-GIS

\section{Introduction}

Crop Wild Relatives (CWR) and Landraces (LR) occupy a unique place within biodiversity since it is directly linked to food and agriculture, essential for sustaining the basic needs of humankind and safeguarding world's food security (CBD 2002). Both the Convention on Biological Diversity (CBD) and the International Treaty on Plant Genetic Resources for Food and Agriculture (ITPGRFA) are stressing the 
needs for more efforts at the national and global levels for effective conservation, sustainable use and the equitable sharing of the benefits arising for its utilization (CBD 1992; ITPGRFA 2004). These two binding international agreements along with the Second State of the World (SoWPGRFA) and the Global Plan of Action of Plant Genetic Resources for Food (FAO 1996) are recommending using both ex situ and in situ approaches for conserving agrobiodiversity (Shehadeh et al. 2013).

Conservation and sustainable use of agrobiodiversity in general, and CWR and LRs, plays a major role in increasing food security, improving ecosystem stability and increasing adaptation of agricultural crops to environmental change (Dudley et al. 2010). This role, much needed in the light of rapid population growth, is attributed to their genetic diversity that can be used by plant breeders to produce new varieties resistant to biotic and abiotic stresses and capable of withstanding the adverse effects of climate change (Uprety et al. 2012; Ford-Lloyd et al. 2011; Pandey et al. 2008).

With increased interest in CWR, many treaties addressed the need to conserve and use as much of the gene pool of crops to protect this reservoir for the benefit of plant breeders, farmers, scientific researchers, and increase the crop resilience as well as agroecosystem diversity and sustainability. Despite all efforts, CWR and their natural habitat are threatened by many factors such as deforestation, urbanization, overgrazing, land reclamation, environmental degradation, land use and climatic change. This may result in huge rates of genetic erosion in species, severely reducing their capacity to adapt to evolving ecosystems (Bijlsma and Loeschcke 2012).

The different approaches to conserve agrobiodiversity (ex situ and in situ) in general and CWR diversity necessitate proposing a plan to identify and prioritize target taxa and areas to be conserved (Shehadeh et al. 2013). Gap Analysis, a conservation evaluation technique, is an essential step in this process (Margules and Pressey 2000; Langhammer et al. 2007). This method informs the development of sound conservation strategies or the revision of existing ones by identifying priority species for conservation. This is done through a comparison of natural diversity of target species with actively conserved species, identifying geographic areas rich in underrepresented species, and identifying and characterizing habitats for each species (Shehadeh et al. 2013; Maxted et al. 2008; Margules 1989; Ramirez-Villagas et al. 2010). It has an important facet in facilitating the relative assessment of conservation priorities. For example, taxa that are most threatened will have higher conservation priority compared to those less threatened; those with certain attributes (e.g. drought tolerance) would get a higher priority as well.

Among CWR, Medicago L. (Fabaceae), is one of the most important genera of temperate pastures. It putatively originated in the Fertile Crescent, southern Caucasia and the Mediterranean Basin (Delalande et al. 2006) and the main center of diversity are in Central Asia and Mediterranean Basin. This genus includes the cultivated alfalfa (M. sativa L.) which was first domesticated crop as feed for livestock over 8000 years ago (Lesins 1970). Nowadays, alfalfa is the first economically important forage legume, globally used as a quality fodder for the livestock (Papachristou et al. 1999; Papanastasis et al. 1999). Apart from alfalfa, several annual Medicago species are also cultivated as animal feed and human food (Medicago marina, M. minima, and M. polymorpha) (O’Neill and Bauchan 2000). Other congeners, such as $M$. sativa, are used in phytoremediation (Chekol and Vough 2001) or cultivated in sustainable agricultural ecosystems for their capacity of nitrogen fixation and to provide a disease break for rotational corps (AlAtawneh et al. 2009; Walsh et al. 2001).

All the 85 accepted species in the genus Medicago are essential elements in healthy rangelands and contribute to the genepool of this economically valuable crop (Al-Atawneh et al. 2009). Due to its economic importance, ex situ conservation efforts of Medicago date back to late twentieth century, when many countries established their collections. At the International Center for Agricultural Research in the Dry Areas (ICARDA), the most extensive collection of Medicago species has been established since 1970s. Currently, large collections of Medicago accessions are held at ICARDA's genebank, the Australian Medicago Genetics Resource Center (AMGRC), USDA-ARS (United States Department of Agriculture-Agricultural Research Service) and at the Vavilov Institute (Al-Atawneh et al. 2009). Though large numbers of accessions are conserved, they do not represent all the gene pool, as the majority of Medicago species are poorly represented in the collection especially the perennial Medicago and the 
species recently moved from Trigonella L. to Medicago (Al-Atawneh et al. 2009). To date, there are no in situ conservation sites specifically designated for the conservation and management of Medicago germplasm (Al-Atawneh et al. 2009). Even though they do exist in some protected areas; no specific management plans are applied or developed for these species.

Despite the importance of Medicago, information on these species is limited. The latest revision of this genus is done by Al-Atawneh et al. (2009) which is a modification of Small and Jomphe (1989) and Heyn (1963). In Lebanon, the flora is comprised of circa 3000 species, a relatively high species richness compared to other Mediterranean countries. The most comprehensive account of this flora is Tohme and Tohme (2014); but typical of floras, it provides an incomplete picture of species distributions, in the sense that not all localities where species were documented are listed. So, in effect it gives a snapshot of the distribution of the native species in Lebanon. These species can be found in variation of habitats ranging from coastal areas to mountainous and from humid to arid zones.

However, earlier observations in Lebanon by Post (1932) and Mouterde (1963) predate the transfer of some species from Trigonella to Medicago by Small (1987). Tohme and Tohme (2014) based their work on Post and Mouterde. An ecogeographic survey for Medicago has been conducted in 74 locations in Keserwen, Lebanon. Fourteen spp. were found: Medicago bonarotiana, M. constricta, M. coronate, $M$. lupulina, M. minima, M. orbicularis, M. polymorpha, $M$. praecox, $M$. radiata, $M$. rigidula, $M$. rotata, $M$. rugosa, M. sativa, M. scutellata and M. turbinata (Fahed 1997).

As part of our ongoing work in Lebanon on the conservation of CWR in general and Medicago in particular, we reviewed the conservation status of this genus with the aim of guiding comprehensive and integrative in situ and ex situ conservation strategies and management plans.

\section{Materials and methods}

Collection of existing taxon-level data

A dataset of 35 out of the 37 Medicago species (excluding subspecies and varieties) reported from Lebanon, with localities that could be georeferenced was constructed. Distribution data for these species was obtained from genebank data bases [International Center for Agriculture Research in the Dry Areas (ICARDA)], online sources (Global Biodiversity Information Facilities (GBIF) (http://www.gbif.org)], Genesis, Euro Med Plant Base (http://www. emplantbase.org) and Lebanon-Flora (http://www. lebanon-flora.org) as well and dissertations (Fahed 1997; Post 1932; Mouterde 1986; Al-Atawneh et al. 2009). Whenever accurate coordinates were lacking (data from floras), the locality (village, town or administrative unit) was manually georeferenced and treated as a single point in spatial mapping of genetic diversity. For any given species, a locality reported by more than one reference was considered once in the analysis. In a few cases where the GPS coordinates available for a given locality did not match its geographic location, the coordinates were corrected using Google Earth Pro (2018) and/or DIVA GIS version 7.1.7 (Hijmans et al. 2005). All coordinates were standardized to a single format (decimal degree).

\section{Collection of existing accession level data}

A total of 1113 surveyed and observed records were included in this study; the data originated from literature, online reports, websites, and from online genebank databases.

Data pertaining to the 485 records from literature were gathered as follows: 321 records according to Post (1932), Mouterde (1986) and Tohme and Tohme (2014), 160 records from Fahed (1997), and four records from Lebanon-Flora.

Data for the 628 accessions from genebank databases were obtained from ex situ conserved accessions: 132 accessions from ICARDA, 196 accessions from GBIF and 300 accessions from Genesys. 
Data processing

Locations for all the geo-referenced data were checked by using Google Earth, which was also used to georeference some records made by botanists and ecologists. To avoid errors, geo-referenced data were standardized to a single format (decimal degree) to indicate the coordinates for spatial analysis using DIVA-GIS. Furthermore, the entire database was sorted in alphabetical order of species to identify data with invalid entries or errors which were manually corrected. All the duplicates and unknown locations were removed.

Spatial analysis

DIVA-GIS was used in map construction and subsequent analysis.

Distribution and richness maps

The final dataset used in the construction of distribution maps included 1113 records from 365 georeferenced localities. To construct richness maps using DIVA-GIS, the map of Lebanon was divided into rasters of different sizes; the most suitable size (determined to be $5.5 \mathrm{~km} \times 5.5 \mathrm{~km}$ ) was used in subsequent analyses. Rasters were color-coded based on richness, which is a function of the number of localities within a raster for individual species and high species diversity for the genus. Rasters with no data were colored white.

\section{Complementarity analysis}

Scott et al. (1993) suggested that richness maps could be used for the identification and selection of reserves aimed at species diversity conservation. Complementarity maps could be created and used to identify priority sites for future collection missions and to guide conservation and management plans (VaneWright et al. 1991). Complementarity hotspot maps for the genus and for separate species in Lebanon were constructed (using Point to Grid and Reserve Selection) with the aim of determining the minimum number of areas to conserve all the genetic diversity and identifying important areas for in situ conservation (Rebelo and Sigfried 1992). Complementarity hotspots were determined at the species level by using a raster size of $5.5 \mathrm{~km} \times 5.5 \mathrm{~km}$. Results of this analysis were displayed as sequences, classes and additional classes. Sequences indicate priority cells/ areas for in situ conservation. Classes indicate species richness. Additional classes indicate the number of new species contributed by each additional cell.

Gap analysis: in situ and ex situ conservation

A subset of 632 records obtained from ICARDA genebank database and on-line sources was used in constructing maps for current ex situ and in situ conservation using DIVA GIS and Google Earth. These maps were combined for the gap analysis, which aims at designating priority species and priority areas to be surveyed for filling the gaps in the genebank collections and highlighting species not present in currently protected areas.

Because of lack of in situ conservation data, the GIS maps of Lebanese protected areas were downloaded on Google Earth from Protected Planet (http:// protectedplanet.net/). The occurrence of medics in protected areas was determined by overlaying the maps of these areas with the distribution map of medics in Lebanon. However, since the maps of some Lebanese protected areas, particularly newly designated ones, are not available (Lebanese Ministry of Environment, personal communication), the occurrence of medics in these areas was determined based on the occurrence of these species within the cadastral limits of the newly designated protected area.

Priority species obtained by combining gap analyses of both ex situ and in situ conservation were categorized according to the following criteria: high priority for species with 0-40\% germplasm conserved, medium priority for species with 40-70\% germplasm conserved and low priority for species with $70-100 \%$ germplasm conserved.

\section{Results and discussion}

\section{Taxonomy}

According to the database compiled from literature and genebanks, the genus Medicago in Lebanon is comprised of a total of 38 species $(45 \%$ of all recognized species in the genus) (Table 1). Since Mouterde (1963), seven species were transferred from 
Table 1 The occurrence of Medicago species in Lebanon according to the database compiled from literature

\begin{tabular}{|c|c|c|c|c|c|c|}
\hline Medicago species & Small (2011) & $\begin{array}{l}\text { Al-Atawneh } \\
\text { et al. (2009) }\end{array}$ & $\begin{array}{l}\text { Tohme and } \\
\text { Tohme (2014) }\end{array}$ & $\begin{array}{l}\text { Mouterde } \\
(1986)\end{array}$ & Post (1932) & $\begin{array}{l}\text { Euro + Med } \\
\text { PlantBase } \\
(2006)\end{array}$ \\
\hline
\end{tabular}

\begin{tabular}{|c|c|c|c|c|c|c|}
\hline M. arabica (L.) Huds. & + & + & + & + & + & + \\
\hline $\begin{array}{l}\text { M. astroites (Fisher. and } \\
\text { C.A. Meyer) Trautv. }\end{array}$ & + & + & T. astroites & T. astroites & T. astroites & + \\
\hline M. bonarotiana Arc. & + & + & + & + & + & + \\
\hline $\begin{array}{l}\text { M. brachycarpa } \mathrm{M} . \\
\text { Bieb. }\end{array}$ & + & + & $\begin{array}{l}T . \\
\text { brachycarpa }\end{array}$ & T. brachycarpa & $\begin{array}{l}T . \\
\text { brachycarpa }\end{array}$ & + \\
\hline M. ciliaris (L.) Korcker & $\begin{array}{l}\text { M. ciliaris (L.) } \\
\text { All. }\end{array}$ & + & + & + & + & $\begin{array}{l}\text { M. intertexta } \\
\text { subsp. ciliaris }\end{array}$ \\
\hline M. constricta Durieu & + & + & + & M. globosa & - & + \\
\hline M. coronata (L.) Bart. & + & + & + & + & + & + \\
\hline $\begin{array}{l}\text { M. crassipes (Boiss.) E. } \\
\text { Small }\end{array}$ & + & + & T. crassipes & T. crassipes & T. crassipes & + \\
\hline M. disciformis DC. & - & + & - & - & - & - \\
\hline M. doliata Carmign. & + & + & - & $\begin{array}{l}\text { M. tuberculate } \\
\text { var. aculeata }\end{array}$ & $\begin{array}{l}\text { M. tuberculate } \\
\text { var. aculeata }\end{array}$ & + \\
\hline M. falcata $\mathrm{L}$. & $\begin{array}{l}\text { M. sativa subsp. } \\
\text { falcate var. } \\
\text { falcate }\end{array}$ & + & + & + & + & + \\
\hline M. granadensis Willd. & + & + & - & - & M. granatensis & + \\
\hline M. hypogaea E. Small & + & - & - & $\begin{array}{l}T . \\
\quad \text { aschersoniana }\end{array}$ & - & + \\
\hline M. intertexta (L.) Mill. & - & + & - & - & - & + \\
\hline M. laciniata (L.) Mill. & + & + & - & - & - & + \\
\hline M. littoralis Loisel. & $\begin{array}{l}\text { M. littoralis } \\
\text { Rohbe ex Losel. }\end{array}$ & + & + & + & + & + \\
\hline M. lupulina $\mathrm{L}$. & + & + & + & + & + & + \\
\hline M. marina L. & + & + & + & + & + & + \\
\hline M. minima (L.) L. & $\begin{array}{l}\text { M. minima (L.) } \\
\text { Bartal. }\end{array}$ & + & + & + & $\begin{array}{l}\text { M. minima \& } \\
\text { M. sessilis }\end{array}$ & + \\
\hline $\begin{array}{l}\text { M. monantha (C.A. } \\
\text { Meyer) Trautv. }\end{array}$ & + & + & T. monantha & T. monantha & T. monantha & + \\
\hline $\begin{array}{l}\text { M. monspeliaca }(\mathrm{L} .) \\
\text { Trautv. }\end{array}$ & + & + & $\begin{array}{l}T . \\
\text { monspeliaca }\end{array}$ & T. monspeliaca & $\begin{array}{l}T . \\
\text { monspeliaca }\end{array}$ & + \\
\hline M. murex Willd. & - & + & + & + & - & + \\
\hline M. muricoleptis Tineo & - & + & - & - & - & - \\
\hline M. noeana Boiss. & - & + & - & - & - & - \\
\hline $\begin{array}{l}\text { M. orbicularis }(\mathrm{L} .) \\
\text { Bartal }\end{array}$ & + & + & + & + & + & + \\
\hline $\begin{array}{l}\text { M. orthoceras (Kar. and } \\
\text { Kir.) Trauvt. }\end{array}$ & + & + & - & - & T. orthoceras & + \\
\hline M. polymorpha L. & + & + & + & M. hispida & M. hispida & + \\
\hline M. praecox DC. & + & + & + & + & - & + \\
\hline$M$. radiata $\mathrm{L}$. & + & + & + & + & T. radiate & + \\
\hline M. rigidula (L.) All. & - & + & + & + & + & + \\
\hline$M$. rotata Boiss. & + & + & + & + & + & + \\
\hline M. rugosa Desr. & + & + & + & + & + & + \\
\hline
\end{tabular}


Table 1 continued

\begin{tabular}{|c|c|c|c|c|c|c|}
\hline Medicago species & Small (2011) & $\begin{array}{l}\text { Al-Atawneh } \\
\text { et al. (2009) }\end{array}$ & $\begin{array}{l}\text { Tohme and } \\
\text { Tohme (2014) }\end{array}$ & $\begin{array}{l}\text { Mouterde } \\
(1986)\end{array}$ & Post (1932) & $\begin{array}{l}\text { Euro + Med } \\
\text { PlantBase } \\
(2006)\end{array}$ \\
\hline M. sativa $\mathrm{L}$. & + & + & + & + & + & + \\
\hline M. scutellata (L.) Mill. & + & + & + & + & + & + \\
\hline M. tenoreana Ser. & - & + & - & - & - & - \\
\hline $\begin{array}{l}\text { M. tornata (L.) Mill. } \\
\quad \text { (Syn. M. italica Lam.) }\end{array}$ & $\begin{array}{l}\text { M. italica (Mill.) } \\
\text { Grande }\end{array}$ & $+^{*}$ & - & - & - & - \\
\hline M. truncatula Gaertn. & + & + & + & + & + & + \\
\hline M. turbinata (L.) All. & + & + & + & + & + & + \\
\hline
\end{tabular}

T. = Trigonella L.

When a species is not reported in a reference, it is indicated by minus (-). When the species is reported in a reference using the accepted name, it is indicated by plus $(+)$. When the species is reported in a reference using a synonym, the synonym is used

*Personal communication

the genus Trigonella L., and six subspecies are now recognized as separate species. Five species were reported for the first time by Al-Atawneh et al. (2009). More recently, Small (2011) reviewed the genus comprehensively and updated the names accordingly. Medicago intertexta (L.) Mill. and M. laciniata (L.) Mill., both not observed by Post (1932), Mouterde (1963), and Tohme and Tohme (2014), were included by Al-Atawneh et al. (2009) and Euro Med Plant Base, without localities (Table 1). Tohme and Tohme (2014) mentioned that M. arabica was not found recently, though its presence was confirmed by Post (1932) and Mouterde (1986). Tohme and Tohme (2014) did not include $M$. astroites, $M$. crassipes, $M$. brachycarpa, M. granadensis, $M$. hypogea and $M$. orthoceras which were previously reported by Post (1932) and Mouterde (1986). Al-Atawneh et al. (2009) and the online databases Euro Med Plant Base confirmed that they are present in the Lebanese regions without indicating their georeferenced distribution data (Table 1). The names of the following species, used by Post and/or Mouterde, were changed: $M$. globosa to $M$. constricta, M. tuberculata var. acculeata to $M$. doliata, $M$. hispida to M. polymorpha and $M$. ciliaris to M. minima. Hence, a taxonomic revision of the Lebanese medics is essential for any future conservation effort.
Geographic distribution and species richness

Analysis of the compiled database showed that seven species of Medicago are common, with 60 or more records per species: Medicago polymorpha (129), M. orbicularis (127), M. minima (97), M. rigidula (82), M. truncatula (80), M. coronata (61) and M. doliata (60). Fourteen species, each with 10 records or less, are rare: Medicago intertexta (10), M. murex (8), M. tornata (6), M. arabica (5), M. astroites (5), M. crassipes (5), M. brachycarpa (4), M. disciformis (3), M. muricoleptis (3), M. noeana (3), M. granadensis (1), M. hypogaea (1) and M. orthoceras (1).

The data show that geographically, Lebanese Medicago species are reported in 190 sites all over the country (Fig. 1). Based on their geographic distribution, the species can be classified as:

a. Coastal species, which occur mostly along the coast: Medicago doliata, M. ciliaris, M. littoralis, M. murex, M. marina, M. rugosa, M. truncatula and M. turbinata.

b. Peripheral species, occurring in marginal parts of Lebanon: Medicago dicsiformis, M. muricoleptis and M. noeana.

c. Restricted species: Medicago arabica, $M$. granadensis, M. hypogaea, M. tornata, M. intertexta and M. orthoceras. 


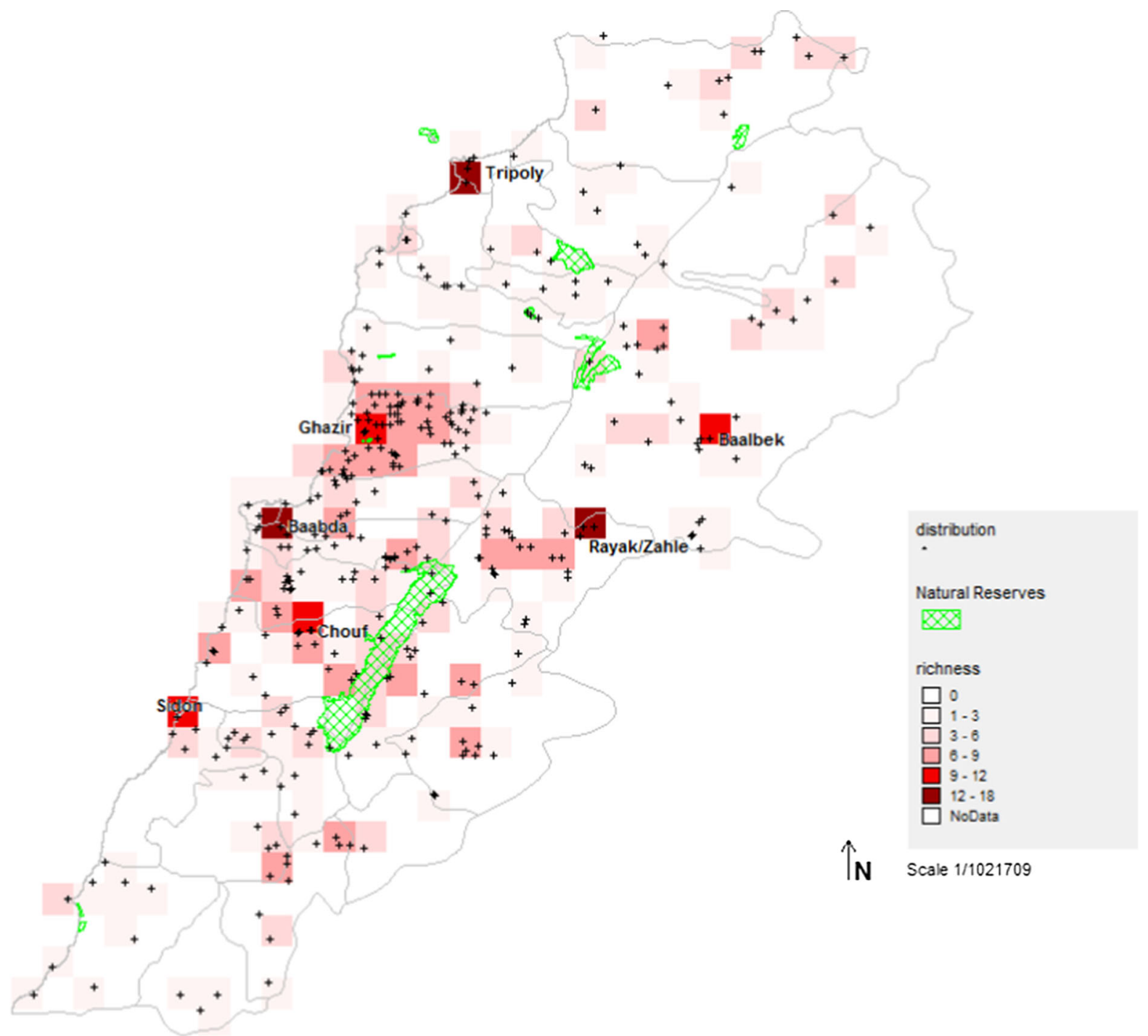

Fig. 1 Species richness and distribution map of all the Lebanese Medicago species over layered with the Lebanese natural reserves

d. Widespread species: Medicago constricta, $M$. coronata, M. lupulina, M. minima, M. monspeliaca, M. orbicularis, M. polymorpha, M. praecox, $M$. radiata, $M$. rigidula, $M$. sativa, $M$. scutellata, Medicago astroites, M. bonarotiana, M. brachycarpa, M. crassipes, M. monantha and M. rotata.

Species richness and distribution maps showed that the Lebanese Medicago are mostly concentrated in the central part of the country in the coastal regions (Beirut, Ghazir, Sidon and Tripoli) and in the Central Beqaa region (West Beqaa and Zahle) with 12-18 reported species, with sparse observations from North
Lebanon (Akkar, Batroun, Koura, Minieh/Donieh and Zgharta), South Lebanon (Bent Jbeil, Hasbaya, Jizzin, Nabatieh, Sidon and Sour), North Beqaa (Qaa, Hermel, Aarsal, Chlifa, Ain, Kneisseh, Fekha, Labweh), and at the Lebanese borders where they have a richness of zero to three species (Fig. 1).

Three factors explain this discrepancy in richness and distribution. The first one is related to the skewness of the data towards richness in Keserwan district. This is due to the fact that we obtained a substantial amount of the distribution data, focused on the central part of the country, especially in Keserwen district, from Fahed (1997). The second factor might 
be related to the focus on dry regions of the country since ICARDA's collecting missions prioritizing dry areas in the Beqaa region, which is most extensively surveyed for Medicago species. The third and last factor is the collector's tendency to emphasize easily accessible areas, which explains why all the observed species were concentrated in the central and Beqaa regions of the country, with gaps in many underrepresented regions.

These gaps in the regions (in white in Fig. 1) may potentially be more species rich than currently known but they are still poorly surveyed.

The current distribution might be misinformed and not representative of the Lebanese territory due to the inaccessibility of some locations mainly in South Lebanon and along the Eastern borders. A comprehensive ecogeographic survey based on the monograph by Al-Atawneh et al. (2009) is required at the level of the entire country, particularly in areas less surveyed. Lebanese coastal regions should be checked to confirm whether Medicago species still survive, despite uncontrolled urban development and habitat loss, in some remnant patches.

\section{Gap Analysis}

In situ conservation and Complementarity analysis

Lebanon has fifteen protected areas located in different geographical regions (Al Chouf, Arz Tannourine, Beit Leef, Bentael, Debl, Horsh Ehden, Jaj, Kafra, Karm Chbat, Mashaa Chnaniir, Palm Island, Ramya, Tyre, Yammouneh and Wadi Houjair). Based on Lebanon Flora and the plant checklist of Lebanese nature reserves, seven species are reported from one to four protected areas and are therefore conserved in situ (Table 2). However, when the distribution map of the Lebanese Medicago species, constructed from the compiled data base, was overlaid with available maps of the Lebanese protected areas, different presence locations were found to fall inside four protected areas (Fig. 2). Accordingly, Al Chouf and Tyre Nature Reserves have the highest concentration of Medicago species with 7-13 species; Arz Tannourine, Horsh Ehden, Machaa Chnaniir and Yammouneh have 3-5 species; and Debl, Jaj and Wadi Hojair present one species each (Table 3). No information about the presence of Medicago species in the other six protected areas is available.

Of the 38 species of Medicago present in Lebanon, twenty were found in protected areas. The remaining 18 species (M. arabica, M. astroites, M. bonarotiana, M. ciliaris, $M$. constricta, M. coronata, $M$. disciformis, M. granadensis, $M$. hypogea, $M$. intertexta, $M$. laciniata, M. littoralis, M. murex, M. muricoleptis, $M$. noeana, $M$. orthoceras, $M$. tenoreana, $M$. tornata) present a gap for in situ conservation.

Complementarity analysis was conducted to determine the 10 most important areas/sites for in situ conservation required to capture all the Lebanese Medicago species (Fig. 3a), and the nine most important areas/sites for all the 18 priority species identified from Table 3 (Fig. 3b).

The generated complementarity maps reveal different important sites located on the coast, in Akkar (Syndieneh and Wadi Khalid), in South Lebanon (Houla and Deir Mimas), and in Beqaa, in addition to Rachaya and Sannine (Fig. 3b). The maps also show that the most important sites are:

1. Wadi Khaled: this area, located at the Lebanese/ Syrian border, is the most important area for priority species and the second important area for all species. This finding is in accordance with Maxted et al. (2012) who considered the Lebanese/Syrian border a priority site for in situ
Table 2 The occurrence of Medicago species in the protected areas according to the final report of the natural reserves and to lebanon-flora

The occurrence of the species is indicated by the sign plus $(+)$ in the table

\begin{tabular}{lllll}
\hline Medicago Species & Al Chouf & Arz Tannourine & Horsh Ehden & Tyre \\
\hline M. falcata L. & + & & + & \\
M. lupulina L. & + & + & + & + \\
M. marina L. & & & + & + \\
M. minima (L.) L. & + & + & + \\
M. sativa L. & + & & + \\
M. scutellata (L.) Mill. & & & \\
M. turbinata (L.) All. & & & & \\
\hline
\end{tabular}




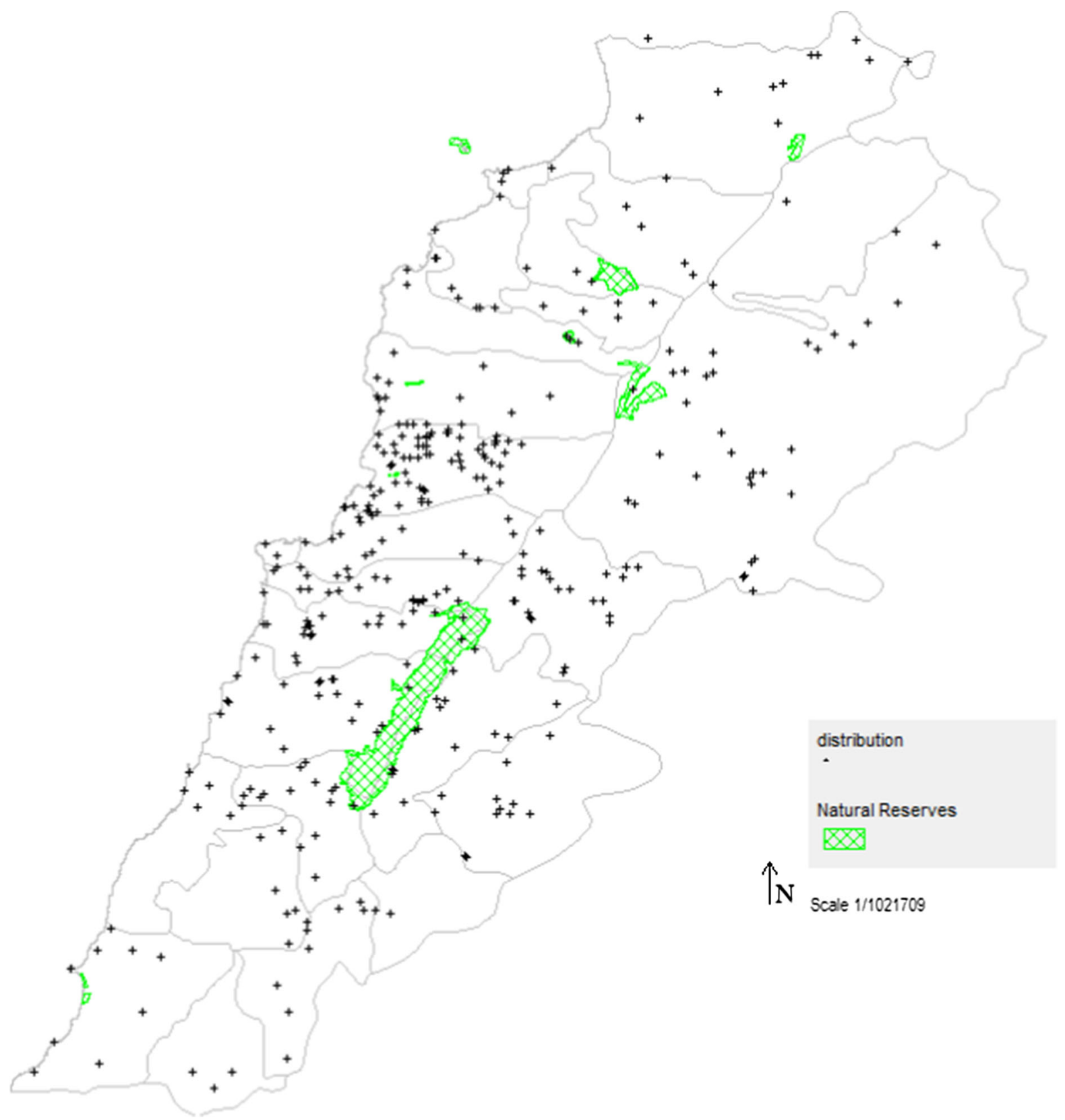

Fig. 2 Distribution map of all the Lebanese Medicago species over layered with the Lebanese natural reserves. The protected areas were installed on the map using protected planet, only nine

conservation for different species of the Fabaceae including Medicago.

2. Tripoli: this coastal area is the second important area for the priority species and the first important site for all the species. Priority needs to be given to this area which has been facing an uncontrolled of the fifteen protected areas have polygon layers can be shown on the maps (Al Chouf, Arz Tannourine, Bentael, Horsh Ehden, Karm Chbat, Mashaa Chaniir, Palm Island and Tyre)

urban sprawl causing habitat loss and leaving very small patches where Medicago may be found. Palm Islands nature reserves is near Tripoli and has a similar microclimate suggesting that Medicago species reported from Tripoli may also 
Table 3 The occurrence of Medicago species in the protected areas by the overlay the distribution of the species with the protected areas

\begin{tabular}{|c|c|c|c|c|c|c|c|c|c|}
\hline Medicago Species & $\begin{array}{l}\text { Al } \\
\text { Chouf }\end{array}$ & $\begin{array}{l}\text { Arz } \\
\text { Tannourine }\end{array}$ & Debl & $\begin{array}{l}\text { Horsh } \\
\text { Ehden }\end{array}$ & Jaj & $\begin{array}{l}\text { Machaa } \\
\text { Chaniir }\end{array}$ & Tyre & Yammouneh & $\begin{array}{l}\text { Wadi } \\
\text { Houjair }\end{array}$ \\
\hline M. brachycarpa M. Bieb. & + & & + & & & & & & \\
\hline $\begin{array}{l}\text { M. crassipes (Boiss.) E. } \\
\text { Small }\end{array}$ & & & & & & & & + & \\
\hline M. doliata Carmignani & & & & & & & + & & \\
\hline M. falcata $\mathrm{L}$. & + & & & + & & & & & \\
\hline M. lupulina $\mathrm{L}$. & + & + & & + & & & & & \\
\hline M. marina $\mathrm{L}$. & & & & & & & + & & \\
\hline M. minima (L.) L. & + & & & + & & & + & & \\
\hline $\begin{array}{l}\text { M. monantha (C.A. Meyer) } \\
\text { Trautv. }\end{array}$ & + & + & & & & & & + & \\
\hline M. monspoliaca (L.) Trautv. & + & & & & & + & & & \\
\hline M. orbicularis (L.) Bartal & + & + & & & & + & & & \\
\hline M. polymorpha $\mathrm{L}$. & & & & & + & + & & & \\
\hline M. praecox D.C. & + & & & & & + & + & & \\
\hline M. radiata $\mathrm{L}$. & + & & & & & & & + & \\
\hline M. rigidula (L.) All. & + & & & & & & & & + \\
\hline M. rotata Boiss. & + & & & & & & & & \\
\hline M. rugosa Desr. & + & & & & & + & & & \\
\hline M. sativa $\mathrm{L}$. & + & & & + & & & & + & \\
\hline M. scutellata (L.) Mill. & & & & & & & + & & \\
\hline M. truncatula Gaertner & & & & & & & + & & \\
\hline M. turbinata (L.) All. & & & & & & & + & & \\
\hline
\end{tabular}

The occurrence of the species is indicated by the sign plus (+) in the table

occur there; however, records from this region are lacking.

3. Houla and Deir Mimas: those sites present one or two species that are endemic to the sites or to the region. These species maybe conserved in situ through the establishment of microresereves. Alternatively, and more practically, these species must be collected and conserved ex situ.

4. Baabda/Beirut, Zahle and Rachaya: these sites are important for species collection as they present a high number of species.

Ex situ conservation

Four hundred fifty-four accessions of Medicago were so far collected from 179 sites most prominently by ICARDA and Kew.
Priority species for ex situ conservation

The largest collection of Lebanese Medicago species, composed of 148 out of the 454 accessions, is at Kew. Another remarkable collection is present at the ICARDA genebank and is comprised of 114 accessions. The most sampled species are: Medicago orbicularis (72 accessions), M. minima (65) and $M$. polymorpha (51) representing $11 \%$ of the total recorded species. Species with less than 10 samples conserved in ex situ are Medicago radiata (8), $M$. littoralis (5), M. intertexta (5), M. ciliaris (4), $M$. noeana (4), M. scutellata (4), M. disciformis (3), M.

Fig. 3 a Complementarity analysis map of all the Medicago species. b: Complementarity analysis map of the priority species (18) for in situ conservation 


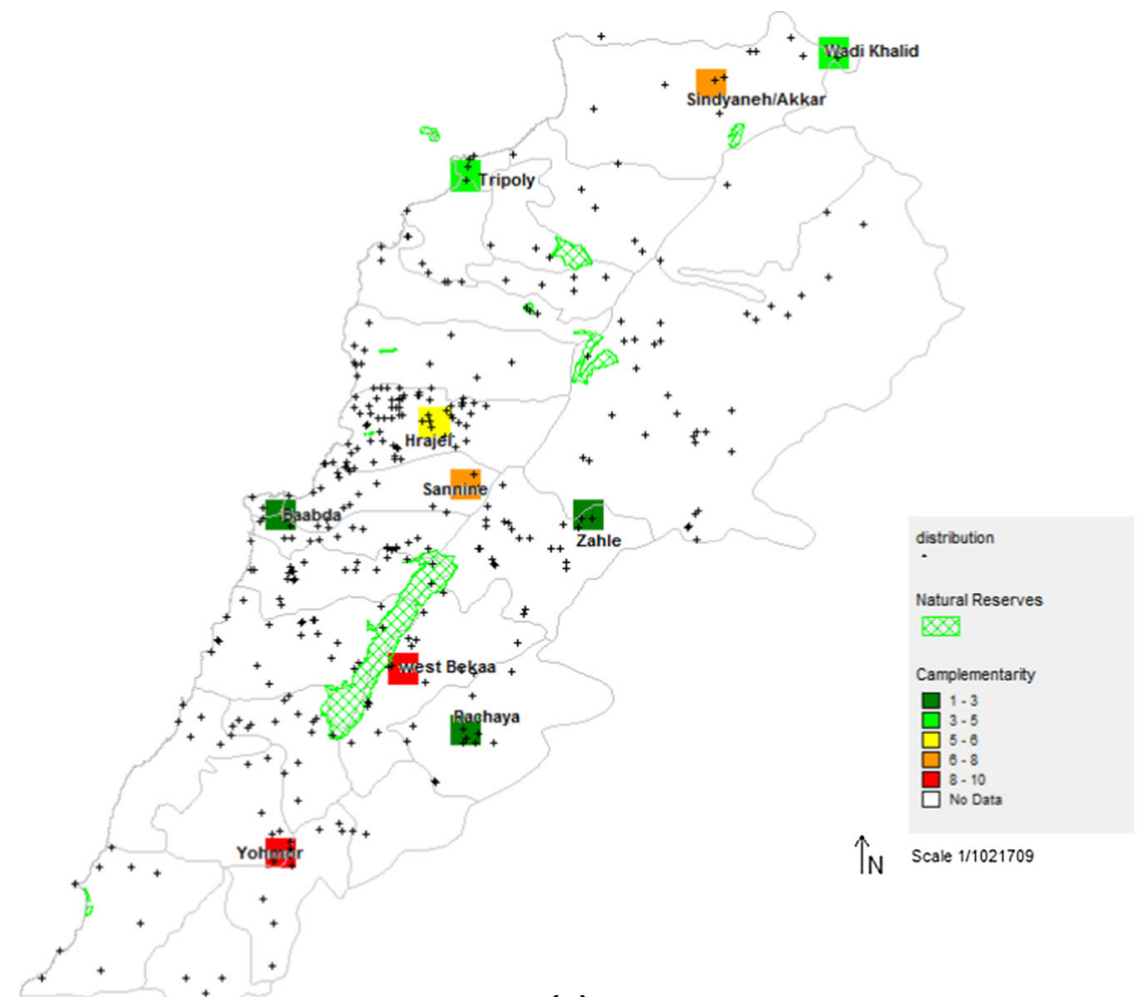

(a)

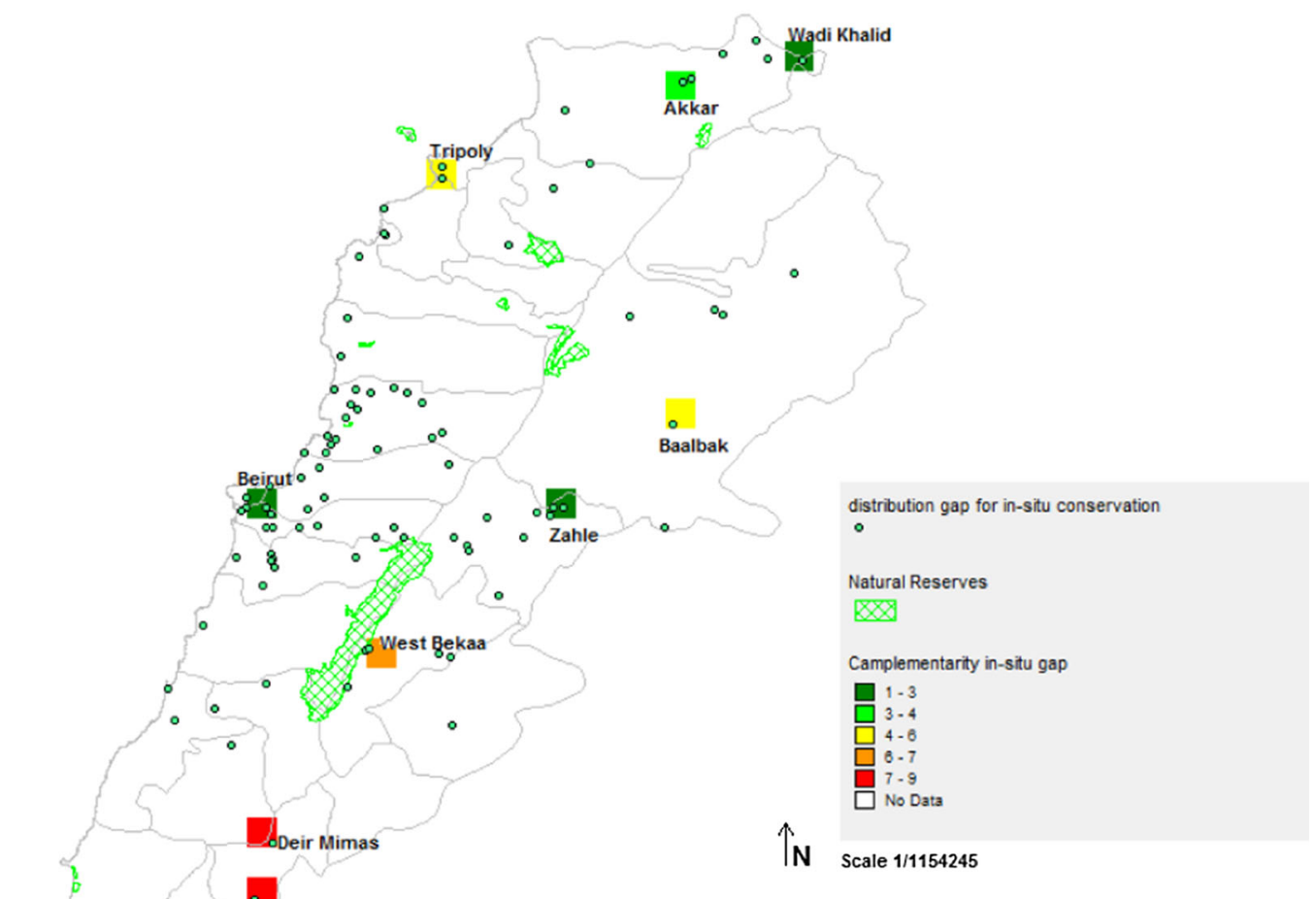

(b) 
monantha (3), M. muricoleptis (3), M. tornata (2), $M$. marina (1). Species with zero samples (Medicago arabica, M. astroites, $M$. brachycarpa, M. crassipes, M. granadensis, M. hypogaea, M. murex and $M$. orthoceras) were previously described as Trigonella.

The priority species for ex situ conservation constitute $48 \%$ of the total Lebanese Medicago species, and are not conserved in genebanks. Our results confirm the classification adopted by Maxted et al. (2004):

1. Category 1 -these are priorities as they do not have any geographical records listed in any of the references: Medicago laciniata and M. tenoreana

2. Category 2-these are rare species that have a restricted/narrow distribution and were collected from one or two sites: Medicago disciformis, $M$. intertexta, M. muricoleptis, M. noeana and $M$. tornata

3. Category 3-these species are also priorities as they do not have any record in gene banks: Medicago arabica, M. astroites, M. brachycarpa, M. crassipes, $M$. falcata, $M$. hypogea, $M$. granadensis, M. murex and M. orthoceras

4. Category 4-these are priority species, as their collected accessions do not represent all the populations per species; most of those accessions were collected from the same sites: Medicago doliata, M. bonarotiana, M. ciliaris, M. littoralis, M. marina, M. monantha, M. monspeliaca, M. radiata, $M$. sativa and $M$. scutellata

Comparing to the table shown in Al-Atawneh et al. (2009), these 14 species with low number of accessions from Lebanon have from 50 to $<200$ accessions conserved at ICARDA genebank except for $M$. sativa and the 12 species that do not have any accessions collected from Lebanon they have $<20$ accessions conserved at ICARDA genebank. These species are the rarest and they are priorities species for ex situ conservation.

Analysis of the records from genebanks revealed that despite the large number of accessions of medics conserved, many are collected from the same region, and many known localities are not represented in genebank collections. For example, Medicago doliata and $M$. radiata are both represented by many accessions (40 and 70 accessions respectively); however, these accessions were mostly collected from the Beqaa. Moreover,
Medicago disciformis, M. muricoleptis, M. noeana and $M$. tornata, are represented by a low number of accessions in genebanks but they are considered priority species because the collected samples are representative of their populations. Therefore, the number of accessions is not always a good indicator of how well conserved a species is, since a small number of accessions representing the natural distribution of a species may be adequate for its proper ex situ conservation.

\section{Priority sites for ex situ conservation}

Gap analysis for the entire genus indicates that most species were collected from the different localities cited in Post (1932), Mouterde (1986) and Tohme and Tohme (2014), especially from the coastal and Beqaa regions. The analysis also shows that there are no accessions collected from localities in Keserwen cited in Fahed (1997), no from sites located in South Lebanon, all of which identified as priority sites for species collection (Fig. 4).

The absence of a gap in the Beqaa may be attributed to the collection efforts of ICARDA, which focuses on the arid and semi-arid regions of the country. The gap in south Lebanon may be explained by the limited accessibility due to persisting security issues.

Two out of 21 species located in Zahle have restricted/narrow distribution (Category 2). $M$. tornata was not indicated in the literature review but it was recorded in ICARDA genebank database. Akkar presents most of the detected species grouped into the marginal and distinct species such as M. muricoleptis and $M$. dicsiformis, and two species out of the nine species detected in the South have narrow distribution.

The ex situ conservation includes the accessions of $M$. noeana and $M$. tornata species which were not recorded in literature however they have been detected and collected in Zahle and West Beqaa by ICARDA researchers. The literature does not confirm their presence in the country contrary to Al-Atawneh et al. (2009) who confirmed the presence of M. noeana in Lebanon, Syria, Palestine and Jordan.

The collection of the threatened species can be started by detecting the rich sites that represent gap to facilitate a quickly collection mission. The map of 


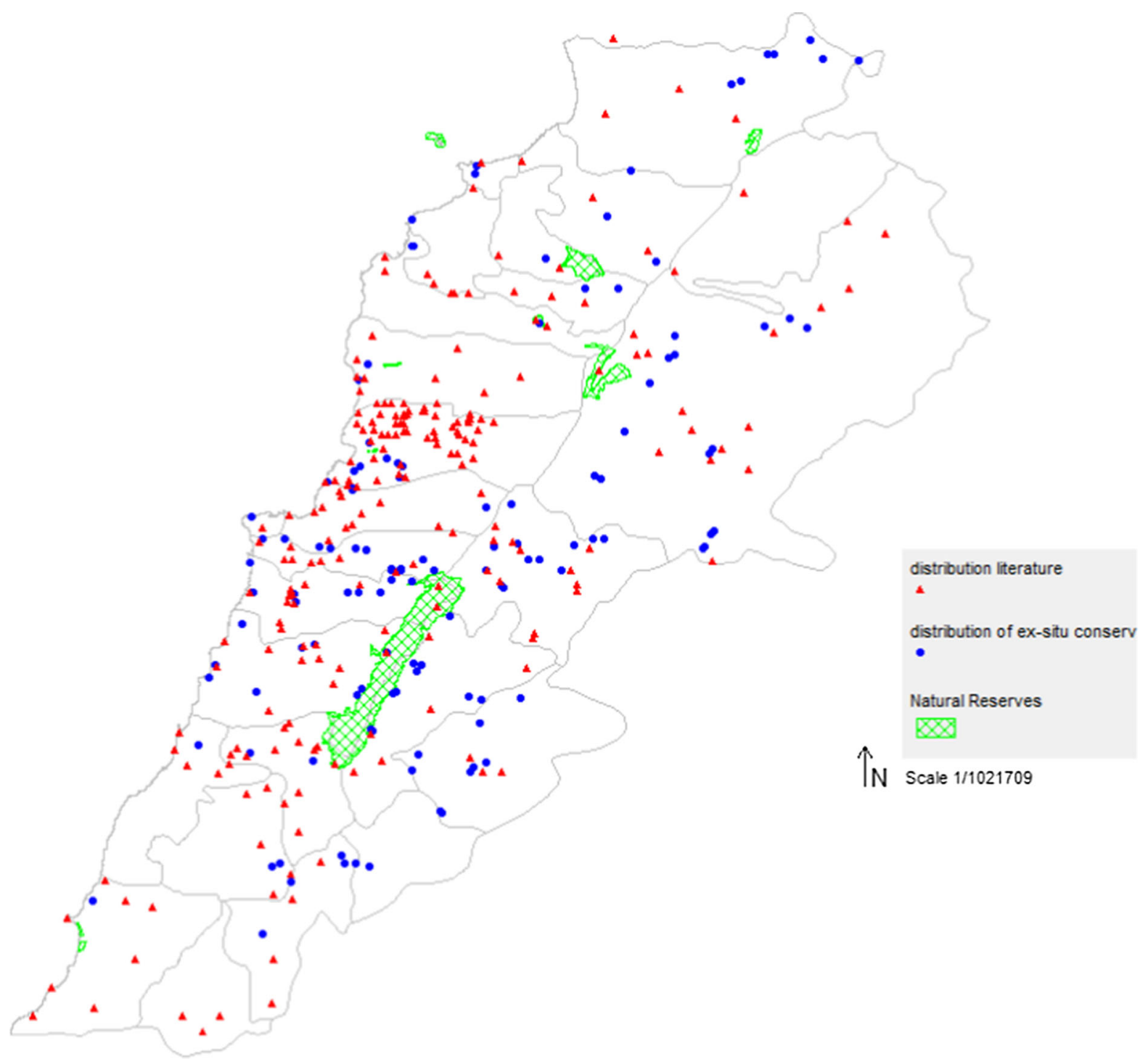

Fig. 4 Gap analysis map. Distribution of ex situ conservation species overlay with distribution of species taken their data from literature

species richness of ex situ conservation shows the most important sites in different regions (Fig. 5).

1. For the Coastal species (M. ciliaris, M. bonarotiana, M. marina and M. scutellata), the collection can be done in Tripoli, Baabda/Beirut and Sidon. These species are heavily threatened by human activities. Their survival is threatened by the loss of their habitat by uncontrolled urban expansion, destruction and/or permanent alteration of the coastal zone, extension of agricultural areas, quarries and sand removal.
2. For the Restricted and Peripheral species: Medicago arabica, $M$. granadensis, $M$. hypogea and $M$. orthoceras that reach the marginal parts of the country, collections from the northern part are available but not the southern part of the country. According to Maxted et al. (2004), these two groups are threatened because they have a narrow distribution.

3. For the widespread species, the collection can be done in Keserwen regions based on the surveys of Fahed (1997). 


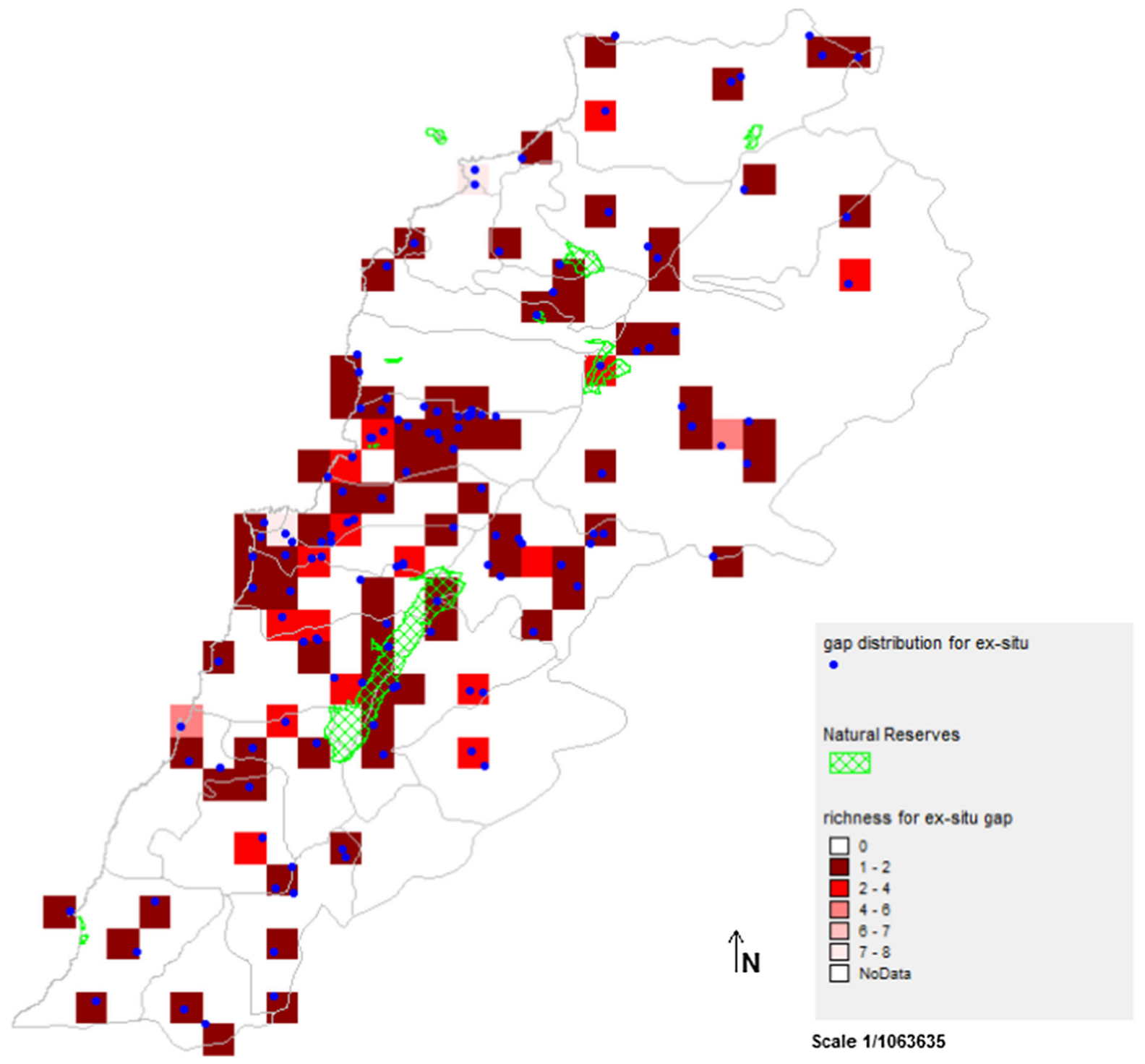

Fig. 5 Richness map for priority species for ex situ conservation

\section{Gap analysis for priority species}

This list of priority species is obtained by combining the two gaps of in situ and ex situ conservation. The results show that eight species are the most important and they are considered as rare. These species are: $M$. arabica, $M$. astroites, $M$. granadensis, $M$. hypogea, $M$. laciniata, M. murex, M. orthoceras and M. tenoreana.

Figure 6 shows the most important sites where these eight species could be found as well as the sites with similar environmental conditions were obtained from complementarity maps and are considered the most important sites for in situ and ex situ conservation except for the species that are present in Deir Mimas and Houla should be conserved in situ because the area is not accessible: M. arabica, M. murex (Tripoli), M. astroites (Beqaa), M. orthoceras and $M$. murex (Baabda/Beirut), M. hypogea (Deir Mimas), and M. granadensis (Houla).

In addition to these eight species, there are other six species that might be found in Lebanon because they are mentioned by Al-Atawneh et al. (2009) in the neighboring countries or because they are mentioned only by Euro Med Plant Base. These six species are: 


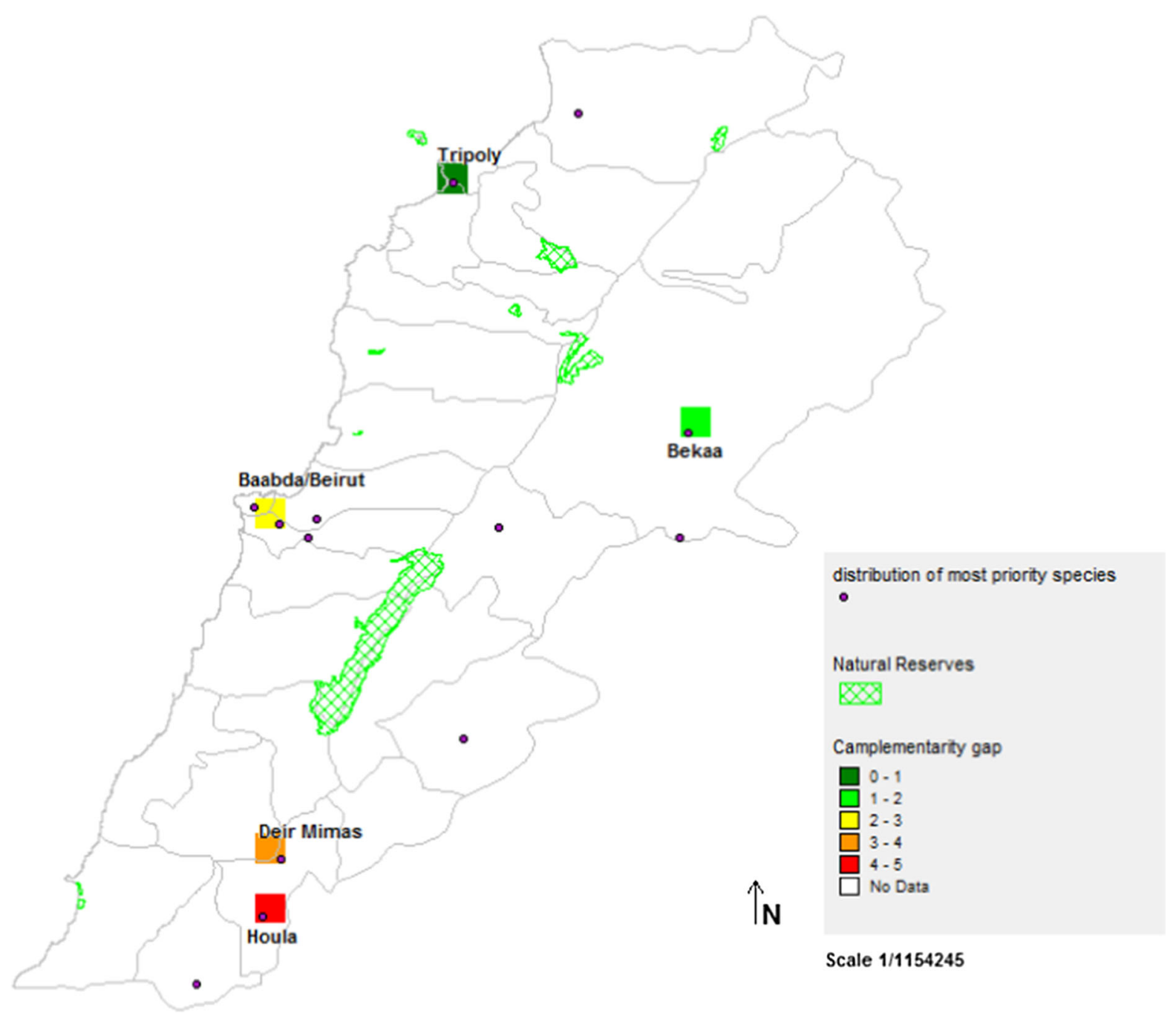

Fig. 6 Complementarity map of the most priority species obtained from gap analysis

(a) M. arborea L., M. phrygia (Boiss. \& Bal.) E. Small, Medicago biflora (Griseb.) E. Small and M. soleirolii Duby could be found in Beqaa, (b) M. lesinsi E. Small could be found in the South, and (c) M. sauvagei could be found in the Beqaa even if it is only mentioned in Morocco but also it was mentioned that is present in Syria by Al-Atawneh et al. (2009).

\section{Conclusion}

The conservation strategies are often hindered by problems with the surveying and collecting to insure the long-term security of the species. This is not only due to high cost of the ex situ conservation but to the difficulty in identifying the best areas to detect the priority species and the inadequate surveying of some areas. Many of the sites are identified as hotspot areas because the species are over collected from these sites and they are completely sampled more than other regions, so it is difficult to identify the rich sites for a future detection and collection. The future collection of the non-detected sites can start in the important sites specially in Keserwen. This means there are some areas richer in Medicago species than that indicated by using species richness analysis because their results were obtained on the data of the old observation and the sites and locations have been changed by different factors by time. It is worth noting that subsequent field work conducted during summer 2016 showed that 
several species of medics have broader geographic distributions than the literature review outcomes. Therefore, extensive and comprehensive field work is required to update the distribution maps, generate updated habitat maps, and identify the rare species of medics in Lebanon. Modeling can help to predict the species that might be found in various regions. This can be done only for species for which distribution data is available. However, for species that were not collected previously, targeted collecting is required.

In addition, prediction maps (Fig. 7) could be used for other purpose, such as indicating the areas where the species are well adapted to be used in restoration activities. The maps are generated by combining the climatic conditions with the data of the distribution
(Angelieri et al. 2016). This information is needed because Lebanon is characterized by various microclimatic conditions (UNDP/GEF and MPWT/DGU 2005). Medicago species have variability, they have been evolving in nature and they are constantly changing in response to their environment (Heyn 1963). These characteristics lead us to use this species in rehabilitation program as in situ conservation method which is less costly than ex situ conservation method in the genebank.

A comprehensive survey of the Lebanese territory indicating the common, rare and threatened species is highly recommended. Red-listing should be performed for the conservation and the protection of the genus Medicago. This red-list will be the first for

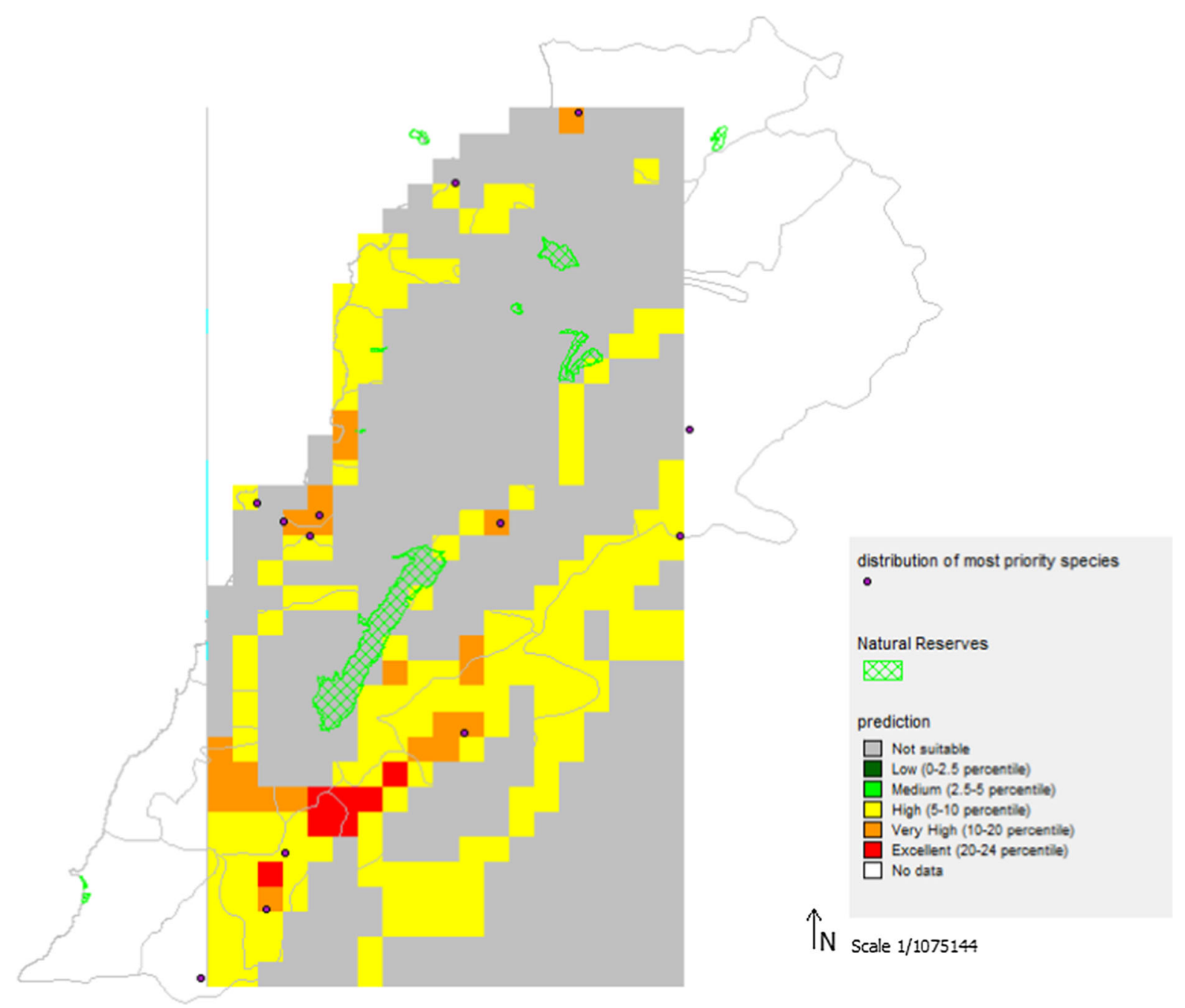

Fig. 7 Prediction map for the most Lebanese priority Medicago species 
annual and perennial plants in Lebanon (ECODIT 2001).

Funding This study was funded by AFESD (Arab Fund for Economic and Social Development) funding provided to ICARDA.

\section{Compliance with ethical standards}

Conflict of interest The authors declare that they have no conflict of interest.

Research involving human participants and/or animals This chapter does not contain any studies with human participants or animals performed by any of the authors.

Informed consent Informed consent was obtained from all individual participants included in the study.

Open Access This article is distributed under the terms of the Creative Commons Attribution 4.0 International License (http:// creativecommons.org/licenses/by/4.0/), which permits unrestricted use, distribution, and reproduction in any medium, provided you give appropriate credit to the original author(s) and the source, provide a link to the Creative Commons license, and indicate if changes were made.

\section{References}

Al-Atawneh N, Shehadeh A, Amri A, Maxted N (2009) Conservation field guide to medics of the Mediterranean basin. ICARDA, Aleppo, pp 1-214

Angelieri CCS, Adams-Hosking C, Ferraz KMPMdB, de Souza MP, McAlpine CA (2016) Using species distribution models to predict potential landscape restoration effects on puma conservation. PLoS ONE 11(1):e0145232

Bijlsma R, Loeschcke V (2012) Genetic erosion impedes adaptive responses to stressful environments. Evol Appl 5(2):117-129

CBD (1992) Convention on Biological Diversity. Secretariat of the Convention on Biological Diversity, Montreal, Quebec, Canada

CBD (2002) Strategic Plan for the Convention on Biological Diversity. Secretariat of the Convention on Biological Diversity, Montreal, Quebec, Canada

Chekol T, Vough LR (2001) A study of the use of alfalfa (Medicago sativa L.) for phytoremediation of organic contaminants in soil. Remediat J 11:89-101

Delalande M, Greene S, Hughes SJ, Nair R, Huguet T, Aouani ME, Prosperi JM (2006) Medicago truncatula Resources chapter, Wild accessions/populations. In the Medicago truncatula handbook. http://www.noble.org/ MedicagoHandbook. Accessed 14 Dec 2018

Dudley N, Stolton S, Belokurov A, Krueger L, Lopoukhine N, MacKinnon K, Sandwith T, Sekhran N (2010) Natural solutions: protected areas helping people cope with climate change. IUCNWCPA, TNC, UNDP, WCS, The World
Bank and WWF, Gland, Switzerland, Washington DC and New York, USA

ECODIT (2001) Lebanon State of the Environment Report. Chapter 10, Biodiversity and Natural Heritage, Ministry of Environment and Lebanese Environment and Development Observatory (LEDO), Beirut, pp 145-162

Euro Med Plant Base (2006) The Information resource for EuroMediterranean plant diversity http://www.emplantbase. org/home.html. Accessed 14 Dec 2018

Fahed R. (1997) Contribution a l'etude ecogeographique des Medicago dans Keserwen (Mount-Lebanon). Dissertation, Lebanese University, Faculty of Agriculture

FAO (1996) The state of food and agriculture 1996. Food and Agriculture Organization of the United Nations, Rome

Ford-Lloyd BV, Schmidt M, Armstrong SJ, Barazani O, Engels J, Ge S, Hadas R, Hammer K, Kell SP, Kang D, Khoshbakht K, Li Y, Long C, Lu BR, Ma K, Nguyen VT, Qiu L, Song G, Wei W, Zhang Z, Maxted N (2011) Crop wild relatives-undervalued, underutilized and under threat? Bioscience 61(7):559-565

Google Earth Pro Ver. 7.3 (2018) http://www.google.com/earth/ download/. Accessed Mar 2018

Heyn CC (1963) The annual species of Medicago. Scr Hierosolymitana 12:1-154

Hijmans RJ, Guarino L, Jarvis A, O'Brien R, Mathur P, Bussink C, Cruz M, Barrantes I, Rojas E (2005) DIVA-GIS 7.1.7. http://www.diva-gis.org

International Treaty on Plant Genetic Resources for Food and Agriculture (2004) http://www.fao.org/3/a-i0510e.pdf

Langhammer PF, Bakarr MI, Bennun LA, Brooks TM, Clay RP, Darwall W, De Silva N, Edgar GJ, Eken G, Fishpool LDC, da Fonseca GAB, Foster MN, Knox DH, Matiku P, Radford EA, Rodrigues ASL, Salaman P, Sechrest W, Tordoff AW (2007) Identification and gap analysis of key biodiversity areas: targets for comprehensive protected area systems. IUCN, Gland

Lesins K (1970) Alfalfa. Lucerne Medicago sativa (Leguminosa-Papilionatae). In: Simmonds NW (ed) Evolution of crop plants. Longman Group, London, pp 165-168

Margules CR (1989) Introduction to some Australian developments in conservation evaluation. Biol Conserv 50:1-11

Margules CR, Pressey RL (2000) Systematic conservation planning. Nature 405:243-253

Maxted N, Mabuza-Dlamini P, Moss H, Padulosi S, Jarvis A, Guarino L (2004) An ecogeographic survey: African Vigna. Systematic and ecogeographic studies of crop genepools 10. International Plant Genetic Resources Institute, Rome, Italy

Maxted N, Dulloo E, Ford-Lloyd BV, Iriondo JM, Jarvis A (2008) Gap analysis: a tool for complementary genetic conservation assessment. Divers Distrib 14:1018-1030

Maxted N, Hargreaves S, Kell SP, Amri A, Street K, Shehadeh A, Piggin J, Konopka J (2012) Temperate forage and pulse legume genetic gap analysis. Bocconea 24:5-36

Mouterde P (1963) Nouvelle flore du Liban et de la Syrie, vol 1. Imprimerie catholique, Beirut

Mouterde P (1986) Nouvelle flore du Liban et de la Syrie, vol 2. Dar el-Machreq editeurs, Beirut

O'Neill NR, Bauchan GR (2000) Sources of resistance in the annual medic core collection. Plant Dis 84:261-267 
Pandey A, Tomer AK, Bhandari DC, Pareek SK (2008) Towards collection of wild relatives of crop plants in India. Genet Resour Crop Evol 55:187-202

Papachristou TG, Platis PD, Papanastasis VP, Tsiouvaras CN (1999) Use of deciduous woody species as a diet supplement for goats grazing Mediterranean shrub lands during the dry season. Anim Feed Sci Technol 80:267-279

Papanastasis VP, Tsiouvaras CN, Dini-Papanastasi O, Vaitsis T, Stringi L, Cereti CF, Dupraz C, Armand D, Meuret M, Olea L (1999) Selection and utilization of cultivated fodder trees and shrubs in the Mediterranean region. CIHEAM, Options Mediterraneennes, Paris

Post GE (1932) Flora of Syria, Palestine, and Sinai. Volume 1, Papilionaceae (Fabaceae) Pea Family (2nd edn, revised by J.E. Dinsmore). American Press, Beirut, pp 320-353

Ramirez-Villagas J, Khoury C, Jarvis A, Debouck DG, Guarino L (2010) A gap analysis methodology for collecting crop genepools: a case study with Phaseolus beans. PLoS ONE 5(10): 13497

Rebelo AG, Sigfried WR (1992) Where should nature reserves be located in the Cape Floristic Region, South Africa? Models for the spatial configuration of a reserve network aimed at maximizing the protection of diversity. Conserv Biol 6:243-252

Scott JM, Davis F, Csuti R, Noss R, Butterfield B, Groves C, Anderson H, Caicco S, D' Erchia F, Edwards TC Jr, Ulliman J, Wright RG (1993) Gap analysis: a geographic approach to protection of biological diversity. Wildl Monogr 123:1-41

Shehadeh A, Amri A, Maxted N (2013) Ecogeograpic survey and gap analysis of Lathyrus L. species. Genet Resour Crop Evol 60(7):2101-2113
Small E (1987) Pollen-ovule patterns in tribe Trifolieae (Leguminosae). Plant Syst Evol 160:195-205

Small E (2011) Alfalfa and Relatives: evolution and classification of Medicago. NRC Research Press, Otawa, p 727

Small E, Jomphe M (1989) A synopsis of the genus Medicago (Leguminosae). Can J Bot 67:3260-3294

Tohme G, Tohme H (2014) Illustrated flora of Lebanon, 2nd edn. CNRS Publication, Beirut

UNDP/GEF and MPWT/DGU (2005) Climatic zoning for buildings in Lebanon, project capacity building for the adoption and application of thermal standards for buildings. United Nations Development Programme, Republic of Lebanon, Ministry of Public Works and Transport, General Directorate of Urban Planning, Beirut, Lebanon

Uprety Y, Poudel R, Shrestha K, Rajbhandary S, Tiwari N, Shrestha U, Asselin H (2012) Diversity of use and local knowledge of wild edible plant resources in Nepal. J Ethnobiol Ethnomed 8(16): 1746-4269

Vane-Wright RI, Humphries CJ, Williams PH (1991) What to protect? Systematics and the agony of choice. Biol Cons 55:235-254

Walsh MJ, Delaney RH, Groose RW, Krall JM (2001) Performance of annual medic species (Medicago spp.) in Southeastern Wyoming. Agron J 93:1249-1256

Publisher's Note Springer Nature remains neutral with regard to jurisdictional claims in published maps and institutional affiliations. 